\title{
Partnership As An Effort To Consolidate Waste Management Initiatives In Tourism Destinations On Small Islands: The Case Of Penyengat Island
}

\author{
Zainul Ikhwan ${ }^{1}$, R.Hamdani Harahap ${ }^{2}$, Lita Sri Andayani ${ }^{3}$, Miswar Budi \\ Mulya $^{4}$ \\ (zainul.ikhwan@gmail.com; r.hamdani@usu.ac.id; lita andayani@yahoo.com; \\ miswarbm_ikl@yahoo.com) \\ Postgraduate Doctoral Student, University of Sumatera Utara and Lecture \\ Environmental Health Study Program, Health Polytechnic of Tanjungpinang, \\ Tanjungpinang, Indonesia ${ }^{1}$ \\ Faculty of Social and Political Science. Universitas Sumatera Utara ${ }^{2}$ \\ Faculty of Public Health. Universitas Sumatera Utara ${ }^{3}$ \\ Faculty of Mathematics and Natural Sciences, Universitas Sumatera Utara ${ }^{4}$
}

\begin{abstract}
Waste management on small islands has challenges, low awareness of the community and culture, limited land, seasonal changes and appropriate waste management technology. Moreover, Penyengat Island is an object of cultural preservation and tourist destination. The purpose of the case study is the small tourist island of Penyengat, Tanjungpinang in waste management through the role of stakeholders and community participation. This type of research is qualitative, and data are obtained by semi-structured interviews and observations. Interviews were conducted with 21 stakeholders in the small island waste management system. (government, private sector, public, universities and professional organizations). Waste management at the location of destisation and cultural preservation requires synergy from all stakeholders including the community. There needs to be a form of compensation for environmental services in tourism development so that an eco tourism tourism package is formed. There is a balance between ecological, economic and social aspects.
\end{abstract}

Keywords: waste management, Penyengat, small island, tourism destinations

\section{Introduction}

Based on Law Number 32 of 2009 explains Environmental Management which is supported and systematically to preserve environmental functions and prevent environmental damage in planning, utilization, control, maintenance, supervision, and law enforcement. Environment as a place of union with all components of objects, conditions, and living things, 
human relationships, which affect nature and live in harmony and balance ${ }^{[1]}$. A lot of assistance for environmental management, one of which is through waste management. Based on Law 18 of $2008^{[2]}$ and Government Regulation 81 Year 2012 ${ }^{[3]}$ explains waste management system in Indonesia has mandated two programs that state the amount of waste and its handling.

Waste management in small island communities such as Penyengat Island, Tanjungpinang City, which is also a cultural and religious tourism island. Tourism islands really need serious waste management because of climatic conditions, topography, lack of funding, inappropriate planning, consumption patterns complexity, tourism flows and seasonal variations will affect the amount and composition of waste ${ }^{[4]}$, lack of excavation of information as a guide as well as time constraints due to the level of mobilization or laziness, as well as the lack of caring ${ }^{[5]}$; ${ }^{6]}$ limited land, land for landfill waste and also requires a high bias in the transportation of waste by sea. Geographically, the location is isolated the need for food and clothing and materials are generally imported with no thought on how to manage the waste generated from these activities. This is exacerbated by the lack of facilities and infrastructure in waste management so that there is no management in the form of a system that manages waste effectively, efficiently and sustainably ${ }^{[7]}$. Improper waste management can result in deteriorating environmental, economic and social quality that is difficult to recover such as the effects of greenhouse gases, land degradation, exploitation of resources resulting from water and soil, air pollution and loss of biodiversity and positive value and attractiveness tourism location ${ }^{[8,9]}$, special attention is especially in Penyengat Island because there are many historical sites and cultural reserves that must be guarded and have special rules in their management.

The way waste management operates in a very complex environment and has different handling priorities ${ }^{[10]}$. For example, tourists do not feel responsible for waste problems because only tourists visit in a short time, do not develop social ties ${ }^{[1]}$ but they should pay for environmental services or environmental compensation. Waste management often only adds costs, especially in the industrial field ${ }^{[12]}$. Based on data from the Department of Public Housing, Settlements, Cleanliness and Cemeteries in Tanjungpinang City in 2016 waste is dominated by $67 \%$ of waste sources originating from households, $10 \%$ market, commercial (ports, shops) $15 \%$, industry $5.2 \%$, roads, parks and rivers $2 \%$. Based on the amount of waste that enters the final waste disposal site in Ganet over a period of 5 years (2010-2014) of $363.53 \mathrm{~m} 3$ / day means the service is less than $52.94 \%$. This happens because of the limitations of the fleet of waste transporters, especially for the transportation of rubbish on small islands and the lack of community awareness in reducing and handling waste.

Penyengat Island is a testament to the history of the Malay Kingdom and is well preserved. The island has only 2,000 meters long and 850 meters wide and is located $2 \mathrm{KM}$ from Bintan Island (the island where the capital of the Riau Islands is located Tanjungpinang). This island is 
known as a tourist destination for religious and cultural tourism. On this island there is the Sultan Riau Mosque, Engku Bilik Palace, Tabik Building, Marhum Palace Office, Putri Well, Ammunition Building, Benteng Bukit Kursi, Indra Perkasa Traditional Hall and several tombs such as the Tomb of Raja Haji Fisabilillah, Tomb of Engku Putri Raja Hamidah, Tomb of Raja Raja Ali Haji etc. Based on the record of the population report of Penyengat Village, the number of inhabitants who inhabited Penyengat Island with an area of $2 \mathrm{~km}^{2}$ in 2017 amounted to 2,760 inhabitants ( 841 households with a density of 690), this number increased from the previous year (2016) which amounted to 2,724 people ( 821 households with a density of 681 ). The estimated amount of landfill in 2016 is $7,763 \mathrm{~m}^{3} /$ day or 1,435 tons/day, and in 2017 it is 7,763 $\mathrm{m}^{3} /$ day or 1,416 tons/day. The amount of waste generation continues to increase considering that there are no waste treatment systems in the sting island.

The development of tourism presents both positive and negative impacts on an area and the community around the tourism activity. The positive impact generated on the economy is opening up employment opportunities, increasing income and increasing infrastructure and public facilities in the tourist destination. But on the other hand, tourism activities can have a negative impact, such as water, soil and air pollution and damage to the natural environment, as well as degradation of moral, social and cultural values and have an impact on public safety and health.

The tourism industry generates additional volumes of waste, especially plastic waste ${ }^{[8,13,14]}$. Generally, tourism activities can produce waste that is almost double the level of local waste production ${ }^{[8]}$. The ability of nature and humans in managing waste is limited ${ }^{[14,15]}$ and the character of tourists will influence the local population with culture and lifestyle ${ }^{[16]}$, so that produces changes in consumption patterns and local waste management according to local potential and conditions.

\section{Methods}

This type of research is qualitative, and data are obtained by semi-structured interviews and observations. Interviews were conducted with 21 stakeholders in the small island waste management system consisting of government stakeholders, related agencies (the Tourism Office, the Environmental Office, the Sanitation Office and the Health Office and the Public Works Department) and the private sector, social institutions, waste service users, the sector informal as well as universities and professional organizations.

\section{Results and Discussion}

Waste management on Penyengat Island is only carried out from house to house, and only a portion of the penyengat community collects waste to be taken by officers to the end of the island and there is no waste processing such as open dumping, as a result the waste will also fall into the sea. Based on a 2010 study conducted in 192 coastal countries by ${ }^{[17]}$, Indonesia became the second largest plastic marine waste disposal in the world after China of around 3.32 million metric tons/year. Marine waste consists of a variety of solid materials both organic and inorganic 
$[18 ; 19 ; 20 ; 21]$. People more often burn rubbish in the open which results in increased levels of $\mathrm{CO}_{2}$ and global warming or throwing trash directly into the sea which has an impact on pollution.

The main problem of waste management on small islands is limited land so it is difficult to carry out waste management such as a large 3R TPS or landfill development. The problem of rubbish on other small islands is during certain seasons such as the north wind season or the holiday season, the waste production will accumulate many times more than usual days, so that the accumulation of waste often occurs. Waste generated on the island as well as coming to the island must be managed with a 3R TPS. The amount of waste often exceeds the capacity that can be handled by the island, due to the limited availability of land for waste disposal, budget funds and human resources. As a result, many solid wastes are burned or discarded by the community and some even dumped directly into the sea ${ }^{[22 ; 23]}$. The process of recycling waste often has difficulty in marketing ${ }^{[4,9]}$. Waste management that is not managed will produce ecological impacts, for example environmental pollution that results in the loss of natural resources; economic impacts such as decreased productivity; social, for example, the emergence of conflict and health.

The 2012-2013 Ministry of Environment and Forestry survey on Environmental Care Concern Index shows that behavior does not sort waste $(76.1 \%)$, burn waste $(38.2 \%)$, household wastewater discharged into rivers, ponds, swamps, sea (15.8\%). Low environmental awareness due to education, age, number of people in the household, knowledge and attitudes and marital status. Cultivation of awareness about environmental quality, will have an impact on attitudes and behavior of waste management and limited use of waste recycling ${ }^{[24 ; 25 ; 26 ; 27]}$ and need good cooperation and interaction for Achieving optimal goals Children are prone to illness when they are born and / or developing in a dense, dirty environment and lack of space for recreation and learning $[28 ; 25]$

Based on the report from the janitor, the janitor in the January-March 2019 area of the coastal area, totaling 3.9 bags $(0.2 \mathrm{~m} 3$ per bag $)$ per day. Based on the results of interviews and field observations, the condition of the waste brought by officers to the TPS location is 1 ton per day, with a rhythm of transportation twice a day which is transported by pick-up (emperor) with a capacity of 1 cubic.

The purpose of synergy is to increase the effectiveness, efficiency and confidence in the sustainability of waste management services on Penyengat Island through increasing understanding and awareness and a sense of need for waste management starting from the reduction and utilization of waste in the household level, so that waste management can be done together and sustainably. The capacity of waste management on Penyengat Island is enhanced through stakeholder involvement, availability and access to facilities and infrastructure. In addition, strong commitment, extensive networks, financial support and transparency and accountability are also needed ${ }^{[29 ; 30]}$

In the operational technical aspects of handling waste on Penyengat Island only takes place collection and removal without the process of transporting and processing or disposing of waste. More open conditions of storage, without sorting out the characteristics and characteristics of waste. The first solid waste management starts from the existing waste source waste ${ }^{[31,32]}$. However, in Penyengat Island there is no individual solidification of waste in each household, as well as open, leaky and uncovered storage conditions that make waste mixed with water, and as a vector nesting site and intruders such as cockroaches, rats that can cause diseases such as diarrhea. Besides that, the waste is still mixed up. Whereas according to Regional Regulation number 3 of 2015, article 27 paragraph 2 (two), the waste sorting and storage facilities should be labeled or marked, differentiated in shape, material and color of the 
container, and using a closed container. Waste that has not been sorted has the potential to produce leachate that can pollute water, and it is difficult to compile or recycle waste.

Waste collection by the community by utilizing the provided container, and among the people living in the coastal area throw it to the beach. Based on 2 (two) types of collection patterns of the Indonesian National Standard (SNI), the Penyengat Island community uses a communal pattern facilitated by the local government. The communal pattern procedure is implemented through village officials where officials who have been appointed to service cleanliness, collect and carry waste to the Temporary Disposal Site, or containers to be taken to the Final Disposal Site, while the means of collecting on a three-wheeled motor that have waste sorting is effective and effective. efficient ${ }^{[33]}$. While the waste collection process on Penyengat Island uses the pick-up service (the emperor) because of different road access conditions from the mainland area of Tanjungpinang City. Waste collected and brought to the end of Penyengat Island is stacked and without treatment the waste management produces leachate and has the potential to pollute water, soil and the environment.

Result of qualitative research were implemented by means of Focus Group Discussion.

1. Increase public knowledge about waste management,

2. The regional government must provide adequate facilities and infrastructure for waste management.

3. Declaration of the Waste Management program (focus on reducing and handling waste) on Penyengat Island

4. Collaboration between the community, government and the tourism sector in creating tourism packages that are environmentalists

5. There are forms of regulation in the form of fees for environmental services

6. The existence of an environmental education package system

Then the process of collecting and transferring also does not occur as a result of sorting waste, so that the conditions of the waste moved by the officials are mixed in one container, so that waste is often wet when moved. As for the removal of waste using pick-up (emperor) services with a growing rhythm of transportation, from 2 emperors with one transport to 2 emperors with two transportation. Waste transportation is only carried out on rubbish which is on the coast to be taken to the Tanjungpinang City Final Processing Site (TPA) by using a sea access (boat) of 2 (two) pieces. However, the condition of waste in the TPS is not carried out in the process of transportation and processing, so that waste accumulates on one land. Transportation of waste from TPS to municipal landfill has not been carried out with consideration of the relatively large transportation costs. The waste processing carried out from time to time is by burning through community initiatives that bring waste to land that is on land. Therefore, it is necessary to manage waste involving the role of the community by optimizing the 3R Waste Management Site, in order to obtain the most relevant waste management for the coastal areas of Penyengat Island.

Waste management by applying the concept of reduce, reuse, and recycle (3R). First, composting organic waste and collecting inorganic waste to collectors or making crafts. Second, collecting organic waste to the place and collecting inorganic waste. Whereas based on regulation number 3 of 2015 article 36 paragraph 1, waste processing should include activities, compaction, composting, material recycling, and turning waste into energy sources. However, waste processing in the final stages of operational techniques is not carried out so that the waste that is in the Waste Processing Site is not processed. The final solution is to burn the trash, 
causing smoke and potentially causing air and water pollution from leachate and residual residue produced.

The institutional aspect does not yet have a waste management body responsible for waste management, both from the authorized RT / RW and the agency, even though the building facilities have been provided. So that the waste that piled up without being managed, and only carried out the processing of waste by burning it, became a pile of waste that began to rise.

Funding aspects, there are no costs involved in waste management on Penyengat Island, which have been spent by the public in the process of transporting, collecting, and disposing of waste. This is because the process is carried out by the Sanitation Department through the officers. Levies have not been applied because the community's awareness is still very lacking, there have been threats that many people are throwing their trash into the sea, especially coastal communities, and in the mainland, community throwing waste into the bushes or burning in open places openly. On Penyengat Island there is no proceeds from the sale of recycled products because the processing building facilities are deactivated so there are no costs allocated for waste management.

In terms of legal regulations, regional regulations already have legal provisions governing waste management, namely regional regulation number 14 of 2009 and regional regulation number 3 of 2015. However, there is a lack of awareness raising and awareness rising so that many people do not know the waste management provisions and consciously do it sustainably and become a shared responsibility. This is evidenced by the ongoing processing of waste by burning.

Based on Regional Regulation number 3 of 2015-chapter VI article 21 paragraph 1, waste management provisions governing waste management, waste reduction should be done with the principle of 3R covering activities, limiting waste generation, waste recycling, and or reuse of waste. However, due to the lack of delivery in the applicable legal provisions, the waste management has not yet been carried out as the applicable provisions.

The aspect of community participation is still said to be intermediate, so the community cannot be involved on their own initiative, it is still needed guidance and appeal from the RT / RW in mutual assistance activities or community service. There is no initiative to provide waste bins at the sources of waste (households) with already in a separate condition between types and characteristics of waste. Cooperation between the government, the community and business owners or packaging waste owners is needed to move together to carry out $3 \mathrm{R}$ efforts to protect the environment and nature in a sustainable manner. Penyengat Island is a historical city of struggle against invaders, there are many former cannons and fortifications found on this island. One of the tombs of the national hero Raja Ali Haji with his famous work Gurindam 12 is on this island. In addition, there is the Sultan Mosque which still stands strong and is used daily by the community to worship. history of the mosque stone is glued with egg whites. However, the amount of trash around the homes of residents makes tourists less satisfied during a visit to this island.

The piles of waste that littered Penyengat Island should receive special attention. The piles of waste will damage the image of the island which is one of the tourist destinations in Tanjung Pinang. To overcome this waste problem, the City Government of Tanjungpianang cooperates with BUMNs that have CSR funds, such as PT Pelindo, BI, PT Angkasa Pura and others, as do other regions that become tourist destinations such as Belitung, Pulau Seribu and others. Collaboration must also be stronger with fellow government institutions of the Environmental Agency (upstream) to increase public awareness and and in the context of reducing the amount 
and type of waste and the Department of Housing, Settlement, Cleanliness and Gardening of Tanjungpinang City (downstream) for the prevention rubbish.

Community participation in management can take the form of waste planning, construction and action $^{34}$. Based on Regional Regulation number 3 of 2015 regarding waste management article 46 paragraph 2 the role of the community can be done by: (1) giving proposals, considerations and suggestions to local governments, (2) formulating waste management policies, (3) providing suggestions and opinions in settling waste disputes. However, these roles are not yet involved in the stinging Empowerment is a concept that is oriented towards reducing formal and informal barriers, as well as efforts to give strength to the community, institutions and government

The wrong assumption in terms of community participation that local governments must assume responsibility for waste management and the community is not expected to take part or contribute ${ }^{1735}$. The level of community involvement in waste management depends on the initiative of local authorities ${ }^{36}$. Both government agencies and citizens must take an active part in realizing operational efficiency in waste management, and community participation in decision making is mentioned by experts as a socio-cultural aspect ${ }^{37}$ in addition, community awareness and social apathy for solutions ${ }^{38}$. Among many stakeholders, community is the largest stakeholder category in the waste management system and has a multi-faceted relationship with waste management activities ${ }^{39}$. The study also found that when people participated in waste sorting, it would reduce the cost of waste management ${ }^{40}$.

Through a partnership approach, Penyengat Island is designed for a major improvement in their waste management system. It is expected to be a success model, because waste management standards on small islands are at the service level, willingness to pay and waste behavior and practices. Partnerships between community members, government and the private sector address the gaps that usually exist between local residents and the tourism industry at their destination. The capacity of waste management has increased due to stakeholder involvement, facilities and access and increased financial transparency and public accountability

The waste management partnership must continue and grow even better. Synergy is also done with the education sector, in this case schools, especially primary schools, to provide young education for the sake of character building, caring for waste management, caring for the environment and caring for sustainability.

\section{Conclusion}

Waste management at the location of destisation and cultural preservation requires synergy from all stakeholders including the community. There needs to be a form of compensation for environmental services in tourism development so that an eco tourism tourism package is 
formed. There is a balance between ecological, economic and social aspects. Collaboration between the community, government and the tourism sector in creating tourism packages that are environmentalists.

Acknowledgements. A very special gratitude goes out to all down at the Ministry of Health for helping and providing the funding for the research; and postgraduate doctoral University of Sumatera Utara as a place to study.

\section{References}

[1] Kemensetneg, Undang-Undang Nomor 32 Tahun 2009. 2009.

[2] Kemensetneg, "Undang-Undang Republik Indonesia Nomor 18 Tahun 2008 Tentang Pengelolaan Sampah," Kemensetneg, 2008. [Online]. Available: www.bphn.go.id.

[3] Kemensetneg, Peraturan Pemerintah Republik Indonesia Nomor 81 Tahun 2012 Tentang Pengelolaan Sampah Rumah Tangga Dan Sampah Sejenis Sampah Rumah Tangga. 2012, pp. $1-50$.

[4] L. Willmott and S. Graci, "Solid Waste Management in Small Island Destinations: A Case Study of Gili Trawangan, Indonesia," Téoros Rev. Rech. en Tour., p. 71, 2012.

[5] United Nations Environment Programme, "Waste and climate change: Global trends and strategy framework," United Nations Environ. Program., 2010.

[6] United Nations Environment Programme, Sustainable coastal tourism: An integrated planning and management approach. 2009.

[7] H. R. I. Radwan, E. Jones, and D. Minoli, "Managing solid waste in small hotels," J. Sustain. Tour., 2010.

[8] E. Shamshiry, B. Nadi, M. Bin Mokhtar, I. Komoo, H. Saadiah Hashim, and N. Yahaya, "Integrated models for solid waste management in tourism regions: Langkawi Island, Malaysia," J. Environ. Public Health, 2011.

[9] S. Kariminia, S. S. Ahmad, and R. Hashim, "Assessment of Antarctic Tourism Waste Disposal and Management Strategies towards a Sustainable Ecosystem," Procedia - Soc. Behav. Sci., vol. 68, pp. 723-734, 2012.

[10] M. Von Sperling, "Wastewater Characteristics, Treatment and Disposal," Water Intell. Online, 2015.

[11] J. Mateu-Sbert, I. Ricci-Cabello, E. Villalonga-Olives, and E. Cabeza-Irigoyen, "The impact of tourism on municipal solid waste generation: The case of Menorca Island (Spain)," Waste Manag., 2013.

[12] H. Wilts, N. von Gries, and B. Bahn-Walkowiak, "From waste management to resource efficiency-the need for policy mixes," Sustain., 2016.

[13] L. F. Diaz, "Waste management in developing countries and the circular economy," Waste Management and Research, 2017.

[14] T. H. Christensen, Solid Waste Technology \& Management. 2010.

[15] M. C. Chen, A. Ruijs, and J. Wesseler, "Solid waste management on small islands: The case of Green Island, Taiwan," Resour. Conserv. Recycl., vol. 45, no. 1, pp. 31-47, 2005.

[16] P. Balasubramanian, M. Vedhanayagam, G. C. Jayakumar, K. J. Sreeram, J. Raghava Rao, and B. U. Nair, "Studies on Paper and Pulp Industry Waste for Leather Making: An Insight in Converting Waste to Wealth," in Waste Management and Resource Efficiency, 2019.

[17] J. Jambeck, "Plastic Waste Inputs from Land into the Ocean United Nations Open-ended Informal Consultative Process on Oceans and the Law of the Sea," no. June, pp. 13-17, 2016. 
[18] R. Plummer, J. Baird, A. Dzyundzyak, D. Armitage, Ö. Bodin, and L. Schultz, "Is Adaptive Co-management Delivering? Examining Relationships Between Collaboration, Learning and Outcomes in UNESCO Biosphere Reserves," Ecol. Econ., vol. 140, pp. 7988, 2017.

[19] P. G. Ryan, C. J. Moore, J. A. Van Franeker, and C. L. Moloney, "Monitoring the abundance of plastic debris in the marine environment," Philos. Trans. R. Soc. B Biol. Sci., vol. 364, no. 1526, pp. 1999-2012, 2009.

[20] G. Schernewski et al., "Beach macro-litter monitoring on southern Baltic beaches: results, experiences and recommendations," J. Coast. Conserv., vol. 22, no. 1, pp. 5-25, 2018.

[21] S. D. A. Smith and A. Markic, "Estimates of marine debris accumulation on beaches are strongly affected by the temporal scale of sampling," PLoS One, vol. 8, no. 12, pp. 8-13, 2013.

[22] A. B. Alfons and T. Padmi, "Multi-Criteria Analysis for Selecting Solid Waste Management Concept Case Study: Rural Areas in Sentani Lake Region, Jayapura," Indones. J. Urban Environ. Technol., vol. 2, no. 1, p. 88, 2019.

[23] P. J. Deschenes and M. Chertow, "An island approach to industrial ecology: Towards sustainability in the island context," J. Environ. Plan. Manag., vol. 47, no. 2, pp. 201-217, Mar. 2004

[24] A. Anjani, "Household Waste Management in Indonesia :," 2011.

[25] N. Karout and S. Altuwaijri, "Impact of health education on community knowledge, attitudes and behaviour towards solid waste management in Al Ghobeiry, Beirut," East. Mediterr. Heal. J., vol. 18, no. 7, pp. 777-785, 2017.

[26] K. D. Kolbe, "Knowledge, Attitudes and Behaviour regarding Waste Management in a Grammar and a Comprehensive School in England - Results from a School Questionnaire," J. Teach. Educ. Sustain., vol. 17, no. 1, pp. 58-71, 2015.

[27] M. Matsumoto and I. Saizen, "Evaluating school eco-centers at elementary schools in Calamba City, Philippines, and their impact on students' solid waste disposal practices," 2017.

[28] M. Tolvanen, S. Lahti, J. Miettunen, and H. Hausen, "Relationship between oral healthrelated knowledge, attitudes and behavior among 1516-year-old adolescents - A structural equation modeling approach," Acta Odontol. Scand., vol. 70, no. 2, pp. 169-176, 2012.

[29] N. Sinthumule and S. Mkumbuzi, "Participation in Community-Based Solid Waste Management in Nkulumane Suburb, Bulawayo, Zimbabwe,” Resources, vol. 8, no. 1, p. 30, 2019.

[30] N. Yukalang, B. Clarke, and K. Ross, "Barriers to effective municipal solid waste management in a rapidly urbanizing area in Thailand," Int. J. Environ. Res. Public Health, vol. 14, no. 9, pp. 9-14, 2017.

[31] N. F. Haron, S. F. Sidique, and A. Radam, "Examining the Attributes of Electronic Waste Recycling Service: A Choice Modelling Approach,” Asian Soc. Sci., 2017.

[32] R. Faizah, I. Satyarno, H. Priyosulistyo, and A. Aminullah, "Improving the masonry brick ductility using mortar bed joint from rubber tire crumbs: A review," J. Phys. Sci., 2018.

[33] D. R. Wijayanti and S. Suryani, "Waste Bank as Community-based Environmental Governance: A Lesson Learned from Surabaya," Procedia - Soc. Behav. Sci., vol. 184, pp. 171-179, May 2015.

[34] Saragih. Hisarma, D. Subhilhar, R. Hamdani Harahap, and A. Purba, "Actualization of Local Wisdom in Simalungun Ethnics Daily Life,” vol. 136, no. Icosop 2017, pp. 225 $230,2018$.

[35] A. K. Jha, S. K. Singh, G. P. Singh, and P. K. Gupta, "Sustainable municipal solid waste 
management in low income group of cities: A review," Trop. Ecol., vol. 52, no. 1, pp. 123 $121,2011$.

[36] M. I. Al-Wabel, W. S. Al Yehya, A. S. AL-Farraj, and S. E. El-Maghraby, "Characteristics of landfill leachates and bio-solids of municipal solid waste (MSW) in Riyadh City, Saudi Arabia,” J. Saudi Soc. Agric. Sci., vol. 10, no. 2, pp. 65-70, 2011.

[37] M. Fathi, Zangane, Hamed, "Municipal Solid Waste Characterization and It Is Assessment for Potential Compost Production: A Case Study in Zanjan City, Iran," Am. J. Agric. For., vol. 2, no. 2, p. 39, 2014.

[38] H. S. Moghadam and R. J. Stern, "Ophiolites of Iran: Keys to understanding the tectonic evolution of SW Asia: (II) Mesozoic ophiolites," J. Asian Earth Sci., vol. 100, pp. 31-59, 2015.

[39] N. Sharma, “Governance And Women's Group Participation In Solid Waste Management In Nepal A Case of Lalitpur Sub Metropolitan City," no. May, 2017.

[40] P. Agrawal, K. Gupta, V. Mishra, and S. Agrawal, "The Psychosocial Factors Related to Obesity: A Study Among Overweight, Obese, and Morbidly Obese Women in India," Women Heal., vol. 55, no. 6, pp. 623-645, 2015. 